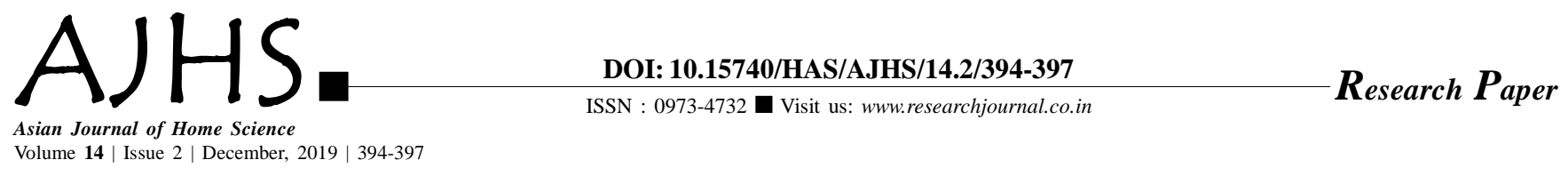

\title{
Assamese hand-woven motifs and development of the center panel designs for Kurti
}

\author{
Syeda Sahnaz Yasmin, Rickey Rani Boruah and Momita Konwar
}

Received: 13.09.2019; Revised: 27.10.2019; Accepted: 11.11.2019

See end of the paper for authors' affiliations

Rickey Rani Boruah

Department of Textiles and Apparel Designing, College of Community Science, Assam Agricultural University, Jorhat (Assam) India

Email : rickey_boruah@

rediffmail.com
ABSTRACT : Assam has a glorious cultural tradition in textiles and handloom weaving. The traditional handloom fabrics of Assam unfold the creative genius of the local weavers. The colours, patterns and designs signify artistic property and social significance. It has been observed that traditional costumes are often decorated with motifs depicting various kinds of plants and animals or their parts, inanimate objects and in some cases abstract art. However, this items are generally found limited to the traditional items. This study was an attempt to popularize the Assamese woven motifs used by the weavers in their textile craft to create Center panel designs for Kurti.

KEY WORDS: Motifs, Center panel, Handloom weaving, Kurti

- HOW TO CITE THIS PAPER : Yasmin, Syeda Sahnaz, Boruah, Rickey Rani and Konwar, Momita (2019). Assamese hand-woven motifs and development of the center panel designs for Kurti. Asian J. Home Sci., 14 (2) : 394-397, DOI: 10.15740/HAS/AJHS/14.2/394-397.Copyright@ 2019: Hind Agri-Horticultural Society. 